\title{
Bearing capacity of Circular footing on Sand Deposit
}

\author{
Aminaton Marto ${ }^{1, \mathrm{~A}}$, Mohsen Oghabi ${ }^{2, \mathrm{~B}^{*}}$ And Nor Zurairahetty Mohd Yunus ${ }^{3, \mathrm{C}}$ \\ ${ }^{1}$ Professor of Faculty of Civil Engineering, Universiti Teknologi Malaysia, 81310 Skudai, Johor \\ Bahru, Malaysia \\ ${ }^{2, *}$ (Corresponding author) PhD Student of Faculty of Civil Engineering, Universiti Teknologi \\ Malaysia, 81310 Skudai, Johor Bahru, Malaysia \\ ${ }^{3}$ Senior Lecturer of Faculty of Civil Engineering, Universiti Teknologi Malaysia, 81310 Skudai, \\ Johor Bahru, Malaysia \\ a aminaton@utm.my, ${ }^{\mathrm{b}}$ mohsenoghabi@gmail.com, ${ }^{\mathrm{c}}$ nzurairahetty@utm.my
}

Keywords: Bearing Capacity, Sand Deposit, Circular Footing, Model Test, ABAQUS.

\begin{abstract}
Bearing capacity and settlement are two important parameters in geotechnical engineering. The bearing capacity of circular foundations on sandy soils is important to geotechnical practicing engineers. Design of foundations includes soil parameters and bearing capacity of foundation. This paper presents the results of laboratory experimental model tests of circular footings supported on sand deposit under static load. The finite element software, ABAQUS is used to compare the results. The effects of the relative density of the sand $(30 \%, 50 \%$, and $70 \%)$ and the diameter of circular footing $(75 \mathrm{~mm}$ and $100 \mathrm{~mm})$ are investigated. It can be concluded that the experimental test results fit quite well with the results of numerical method.
\end{abstract}

\section{Introduction}

Soil is an important material in most of the engineering projects. The size and shape of shallow footings in obtaining the maximum bearing capacity and limiting settlement are essential in geotechnical engineering. Terzaghi (1943) used shape factors for rectangular, square and circle forms in bearing capacity equations and this led to more works done by several researchers to understand the role of shape in improving the bearing capacity of foundation soils. (e.g. Bowles ,1996; Krishnaswamy et al., 2000; Boushehrian and Hataf , 2002; Esmaili and Hataf, 2008 and Latha et al., 2010). Most of these studies focused on optimization of circular footings. Many numerical, analytical and experimental studies have been conducted to evaluate the behavior of soil foundations constructed on various soil types [1-6].

In this study, the bearing capacity of circular footing on dry sand deposit under static load has been investigated. In order to do this, the ABAQUS software was used to test the experimental model and to model the finite element. Then, the results obtained from the experimental test and the results from the numerical modeling were compared.

\section{Experimental Model Test}

The test model was done in a box with dimension $620 \mathrm{~mm}, 620 \mathrm{~mm}$ and $500 \mathrm{~mm}$ of width, length and height. The four sides of the box was made of Plexiglass sheet, $15 \mathrm{~mm}$ in thickness. Two models of circular foundation used were made of steel and they had 75 and $100 \mathrm{~mm}$ diameters and $10 \mathrm{~mm}$ thickness. The footing was put at the centre of the tank. The laboratory model test is shown in Fig.1. The experimental model test was done in a test bed comprising a testing box, loading frame system, measurement equipment and pneumatic jack. The loading frame system includes a loading frame, a pneumatic jack and a pressure controlling unit. The loading frame consists of four steel columns and four horizontal steel beams on top that support the pneumatic jack and four horizontal steel beams at the bottom that support the test box. 


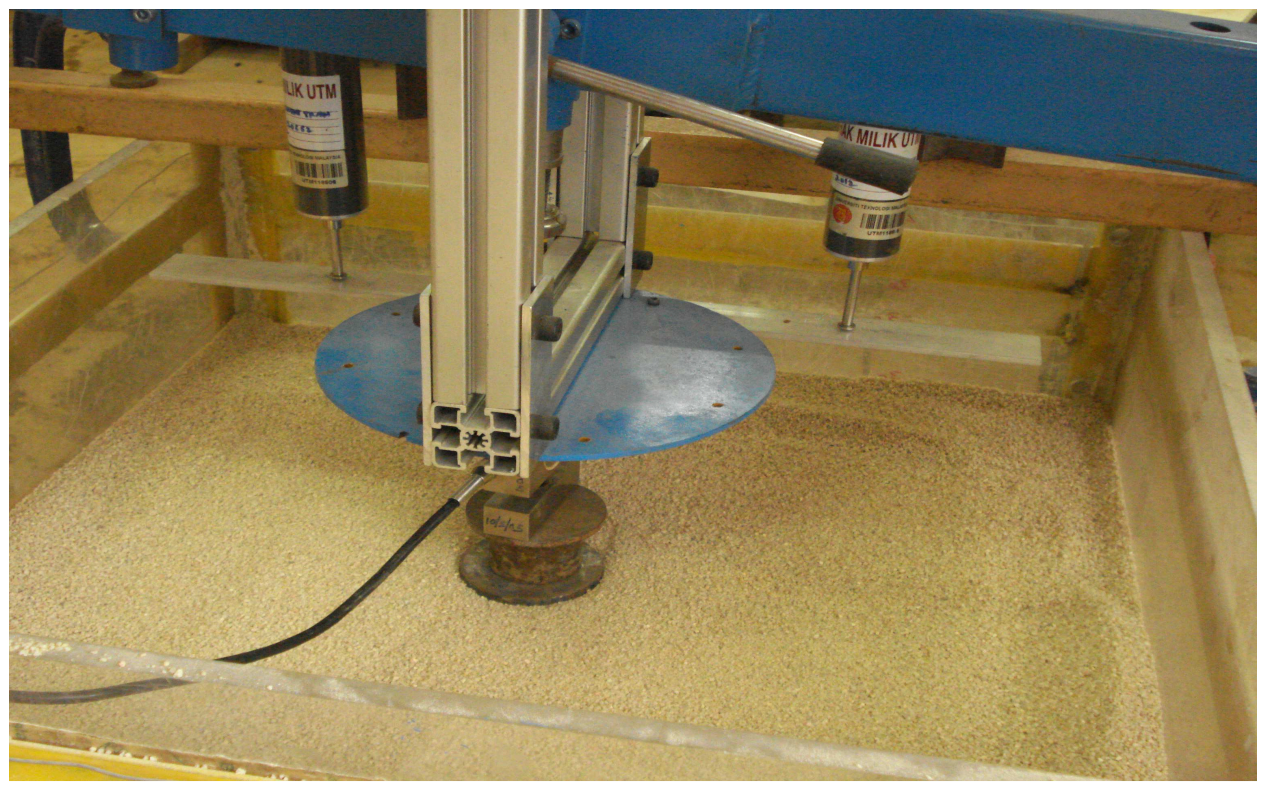

Fig. 1 General arrangements of experimental model test.

The data logger could automatically record results of both settlement and load. For measure load used a S-shape load cell on the circular footing. Also two linear variable differential transducer (LVDT) $(100 \mathrm{~mm})$ to measure amount of settlement was used on the circular footing during the loading test. All of the devices were calibrated prior to each series of tests to ensure an accurate reading.

The soil used in this study was quarry sand with particle sizes between 0.60 and $2.36 \mathrm{~mm}$. It has a curvature coefficient, $\mathrm{C}_{\mathrm{C}}$, of 1.24 , uniformity coefficient, $\mathrm{C}_{\mathrm{U}}$, of 1.88 , effective particle size, $\mathrm{D}_{10}$, of $0.85 \mathrm{~mm}$, and mean particle size, $\mathrm{D}_{50}$, of 1.46 which means that almost all the particles were between 1 and $2 \mathrm{~mm}$ in size. As well as, the specific gravity, Gs, was 2.62. The minimum and maximum void ratio $\left(\mathrm{e}_{\min }\right.$ and $\mathrm{e}_{\mathrm{max}}$ ) of the sand was collected as 0.70 and 0.97 , respectively. According to the British Standard Soil Classification System, the quarry sand is classified as poorly graded sand with letter symbol SP. The minimum and maximum dry unit weights of the sand were found to be 13.27 and $15.40 \mathrm{kN} / \mathrm{m}^{3}$. To obtain the best results, three types of relative density were chosen; they were $30 \%, 50 \%$ and $70 \%$. The friction angle of sand obtained triaxial compression tests on dry sand at $30 \%, 50 \%$ and $70 \%$ relative density were $29.9^{\circ}, 36.2^{\circ}$ and $42.3^{\circ}$, respectively. The physical properties of sand are presented in Table 1 .

Table 1 Physical properties of sand

\begin{tabular}{|l|c|c|c|c|c|}
\hline Property & $\begin{array}{c}\text { Elastic Modulus, } \\
\mathrm{E}[\mathrm{MPa}]\end{array}$ & $\begin{array}{c}\text { Friction Angle, } \\
\varphi\left[{ }^{\circ}\right]\end{array}$ & $\begin{array}{c}\text { Poisson } \\
\text { Ratio, } \mu\end{array}$ & $\begin{array}{c}\text { Unit Weight, } \\
\gamma\left[\mathrm{kN} / \mathrm{m}^{3}\right]\end{array}$ & $\begin{array}{l}\text { Relative Density, } \\
\mathrm{RD}[\%]\end{array}$ \\
\hline Sand 1 & 17 & 29.9 & 0.3 & 13.85 & 30 \\
\hline Sand 2 & 30 & 36.2 & 0.33 & 14.25 & 50 \\
\hline Sand 3 & 53 & 42.3 & 0.35 & 14.70 & 70 \\
\hline
\end{tabular}

The footing was loaded by a hand operated pneumatic jack supported against a reaction frame. The pneumatic jack was connected to the footing through a pre calibrated load cell to measure the loads applied on the footing. Footing settlements were measured through two LVDT located on the footing. In the absence of a clear-cut failure, the loading test was conducted by applying a vertical load continuously to the circular footing until a footing settlement of around $30 \mathrm{~mm}$ was achieved. 


\section{Numerical Model Test}

Circular footings constructed on sand deposit were simulated numerically using the finite element program, ABAQUS. The Mohr-Coulomb criterion was used for modeling the behavior of soil failure stage. The results from numerical models depended on some parameters such as ratio of elements size, increments of load, boundaries, etc. In an accurate numerical process, the parameters had to be set in such a way that they do not affect the results [7]. The choice of element type and number of $3 \mathrm{D}$ elements were made according to the capabilities of the finite element software ABAQUS. This was done in order to yield accurate results along with optimum time of calculation. Hence, a soil with the dimensions of same small scale model of experimental test was modeled underneath the circular footing. The meshing of the soil and foundation is demonstrated in Fig. 2.



Fig. 2 Geometry of 3D modeling in finite element analysis

\section{Results and Discussion}

In this section, the test results of the experimental model and numerical analysis are demonstrated. A discussion focused on the bearing capacity of circular footing. Furthermore, the effects of different parameters including footing diameter and sand relative density on the amount of bearing capacity of sand, are presented.

The Effect of Relative Density of Soil on Bearing Capacity Moghaddas et al. (2011), Cerato and Lutenegger (2008) and Dash et al. (2003) have reported that, the internal friction angle reduces with reduce in soil density [8-10]. The effect of the relative density of sand was studied in the experimental test. Fig. 3 shows the bearing capacity obtained with different relative densities. The Fig. presented the experimental results of the applied pressure on circular footing with the settlement of the footing with diameter of $100 \mathrm{~mm}$ for different relative density of $30 \%, 50 \%$ and $70 \%$. It can be seen clearly that the sand with higher relative density has undergone more surface heaving because of the volumetric expansion. For unreinforced sand load-settlement variation, the failure point was well defined. In addition, the ultimate bearing capacity was easily obtained. The footing pressure at a footing settlement of $0.1 \mathrm{D}$ is taken as the ultimate bearing capacity.

Based on Fig. 3, the key role of the soil density on the footing settlement and bearing pressure was clear. It shows that when the relative density of sand increases, the maximum bearing pressure occurs at a smaller settlement. For example, the amount of bearing capacity for relative densities of $30 \%, 50 \%$ and $70 \%$ were 39,50 and $68.5 \mathrm{kPa}$ at $10 \%$ ratio of settlement (s/D) respectively. This could be attributed to the increase in the soil stiffness due to the increase in the density of sand 
which accommodated a large shear strain in soil beneath the circular footing. The settlement of footing at a given bearing pressure decreased due to the increase of the soil relative density.



Fig. 3 Variation of bearing pressure vs footing settlement for 75 and $100 \mathrm{~mm}$ diameter of footings at different relative density from experimental test

The Evaluation of Diameter of Foundation on Bearing Capacity One of the parameters that affect the settlement of foundations is the foundations' diameter. In order to investigate the effect of diameter on settlement, circular foundations with diameter amount 75 and $100 \mathrm{~mm}$ were modeled with small scale model test and numerical model test. The stress-settlement diagram of the foundations over these soils is demonstrated in Fig. 3. Fig. 3 presents typical results of load curves for the footing tests. These results are for bearing capacity tests. The failure modes for each of the footings vary depending on the sand density. These curves show that the circular footing with 100 $\mathrm{mm}$ diameter have a higher bearing capacity than circular footing with $75 \mathrm{~mm}$ diameter, which is true for the tests on sand and at each density. These state that the slope of elastic lines increased with the reduce in the footing diameter, irrespective of sand relative density.

The Evaluation of Numerical Model Test 3-Dimensional numerical models had been developed in this study to simulate the behaviour of sand under static load. In the model for static loading, the infill sand was modelled using the Mohr - Coulomb model. The effect of size of foundation and relative density was also shown to reduce surface deformation. From this study, there were good agreements between the results from numerical and experimental results.

Fig. 4 shows the field of stress and displacement. The commercial finite element program ABAQUS was used to study the behaviour of circular footings with different diameters. A threedimensional model was adopted to simulate the circular footing over sand deposit. Sensitivity analysis was also conducted to find the degree of mesh refinement to minimize mesh dependent effects and converge upon a unique solution. The footing was regarded as rigid, so applying load on the footing was equal to applying uniform vertical downward pressure at the nodes immediately underneath the footing. Before applying the external load on the footing, the initial gravitational stress condition was established by attributing an initial stress state to the soil at grid points. Stress in the vertical direction is equal to the product of unit self-weight of soil and the distance of the grid points from the surface. Horizontal stresses were obtained using the coefficient of earth pressure at rest, $\mathrm{K}_{0}$. 


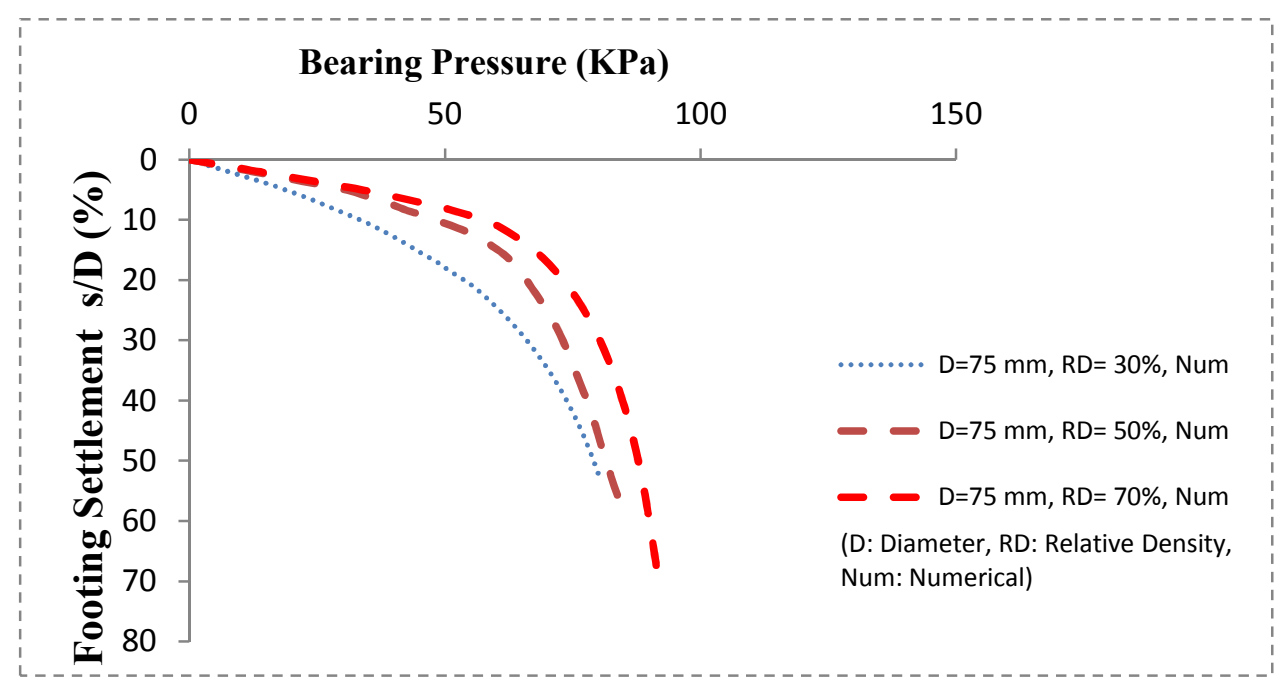

Fig. 4 Variation of bearing pressure vs footing settlement for $75 \mathrm{~mm}$ diameter of footing at different relative density from numerical model

Calibration and Verification of Numerical Model The FEM was first calibrated by comparing the results of model analysis with the static results of laboratory model tests on footing with diameter of $75 \mathrm{~mm}$ for relative density of $30 \%$. Fig. 5 shows the comparison between experimental results and finite element numerical results, which shows that the numerical model can simulate the pressure-settlement behaviour of footing under static load with good accuracy with the maximum difference of $15 \%$. The numerical results agreed reasonably well with the experimental data, indicating that the numerical simulation was promising for estimating the behaviour of footing under static load and may conveniently be used as a tool to evaluate the coefficient of elastic uniform of sand foundation bed and distribution of stress and strain in the bed.

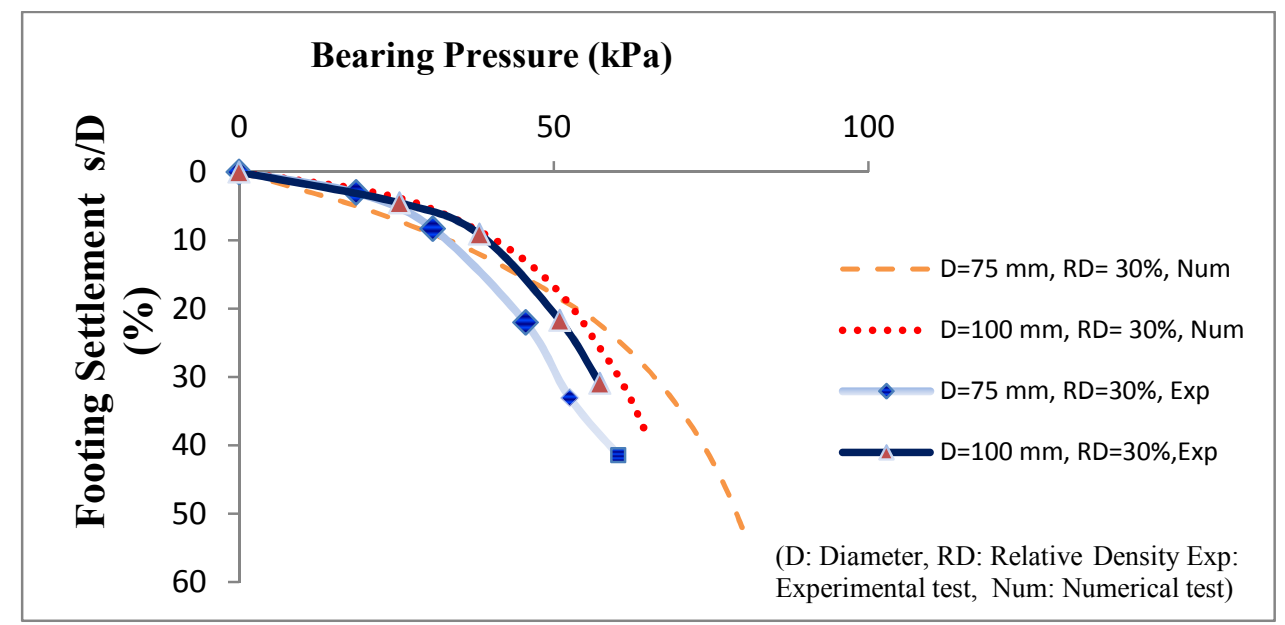

Fig. 5 Comparison between experimental results and finite element analysis for 75 and $100 \mathrm{~mm}$ diameter of footing at $30 \%$ relative densities under static load

\section{Conclusion}

According to Terzaghi's equation, the bearing capacity has a direct relationship with the foundation width. Based on the findings, the following conclusion can be drawn:

1. The bearing capacity of circular footings increases with a relative increase of the density of sand.

2. The diameter of a circular footing has a great effect on its settlement; meaning that under the constant loading conditions, by increasing the diameter of the foundation, the settlement decreases. However, the relationship between settlement and the diameter of the foundation is nonlinear. 
3. The value of bearing capacity of sand is significantly affected by the footing diameter as the value reduces with reduce in the diameter of footing, irrespective of the soil relative density.

4. The comparison between experimental and numerical approaches shows a good compatibility; the maximum difference between two approaches obtained has been about $15 \%$. Thus, this means that the presented numerical model is a reliable model to simulate the behaviour of footings under static loads.

\section{Acknowledgement}

The authors gratefully acknowledged the financial supports given by the Ministry of Education (MOE) through the Universiti Teknologi Malaysia (UTM) under the Research University Grant Scheme (No: Q.J130000.2522.06H60) and the Short Term Research Grant Scheme (No: PY/2013/00870), to undertake this study. The supports from the Construction Research Centre and Construction Research Alliance, UTM are also acknowledged.

\section{References}

[1] K., Terzaghi: Theoretical Soil Mechanics. Wiley, New York, p. 510. (1943).

[2] J.E., Bowles: Foundation analysis and design. 5th ed”, John Wiley\&Sons. (1996).

[3] N.R., Krishnaswamy, K., Rajagopal, G., Madhavi Latha: Model Sstudies on geocell supported embankments constructed over soft clay foundation. Geotech Test J ASTM 23(2000) pp. 45-54.

[4] A.H., Boushehrian, and N., Hataf: Bearing capacity of ring footings on reinforced clay, in Proc. 12th. Conf. of Int. Assoc. for Computer Methods and Advances in Geomechanics (IACMAG), Goa, India, (2008) pp. 3546-3551.

[5] D., Esmaili, and N., Hataf: Experimental and numerical investigation of ultimate load capacity of shell foundations on reinforced and unreinforced sand, Iranian Journal of Science \& Technology, Transaction B: Engineering, Vol. 32 (2008) pp. 491-500.

[6] G. M., Latha, S. K., Dash, \& K., Rajagopal: Numerical simulation of the behavior of geocell geinforced sand in foundations, international journal of geomechanics, 9(4) (2010)., 143-152.

[7] ABAQUS user manual version 6.8. Hibbitt, Karlson and Sorensen, Inc., Pawtucket, RI. (2008).

[8] Tafreshi, S N Moghaddas. et.al.: Experimental and numerical investigation on circular footing subjected to incremental cyclic loads, International Journal of Civil Engineering, 9(4) (2011).

[9] A. B., Cerato, \& A. J., Lutenegger: Scale Eeffects of shallow foundation bearing capacity on granular material, 133(10), (2008) pp. 1192-1202.

[10] S. Dash: Model studies on circular footing supported on geocell reinforced sand underlain by soft clay, Geotextiles and Geomembranes, 21(4), (2003) pp.197-219. 